\title{
STUDI PERBAIKAN BALOK BETON BERTULANG MENGGUNAKAN GLASS FIBRE REINFORCED POLYMER (GFRP) UNTUK MENINGKATKAN KEKUATAN TARIK PADA BENDING MOMEN
}

\author{
Bambang Kiswono ${ }^{1)}$,Edy Jayanto ${ }^{2)}$ \\ Jurusan Teknik Sipil, Universitas Muhammadiyah Surabaya1 \\ J1 Sutorejo 59 Surabaya \\ Email: bambangkiswono.48@gmail.com \\ Praktisi \\ Email:edy jayanto1973@gmail.com
}

\begin{abstract}
Study analysis increase flexture capasity strength reinforced concrete beam and plate with method convensional very difficult site and time schedule make alternative method precise, acceleration time with use Fibre Reinforced Polymer (GRP), There is marketing Glass Fibre Reinforced Polymer, Aramid Fibre Reinforced Polymer, and carbon fibre reinforced Polymer. This product still import from japan, Germany, chinese. This analisys method carbon fibre reinforced polymer study research at building Barbara $6^{\text {th }}$ floor .Test concrete strength with core drill, UPV(Ultrasonic Pulse Velocity) and Profometer.for coredrill 5 point, UPV 10 point, Profometer 10 point.quality concrete K250, analisis data arithmetic reinforced concrete without GFRP sheet and uses GFRP sheet of 2 layers until 5 layers.
\end{abstract}

Keywords: strength flexture,beam and plate,test sample cylinder laboratory,GFRP sheets.

\begin{abstract}
Abstrak
Studi analisis peningkatan perkuatan kapasity lenturr pada balok dan plat dengan metode konvensional sangat menyulitkan saat pelaksanaan dilapangan dan waktu sangat menentukan, sehingga alternative dipakai metode teknologi tepat guna karena adanya percepatan waktu seperti penggunaan Fiber Reinforced Polymer, ada beberapa jenis yang ada dipasaran Glass Fiber Reinforced Polymer , Aramid Fiber Reinforced Polymer dan Carbon Fiber reinforced Polymer. Produk ini masih berasal dari jepang, Jerman, Cina dalam analisis ini digunakan alternative metode Carbon fiber Reinforced Polymer. Pada studi penelitian di gedung wisma Barbara lantai 6, sebagai bahan acuan pada bangunan existing dilakukan test uji dengan core drill, UPV (Ultrasonic pulse velocity) dan profometer . dilakukan test coredrill 5titik, UPV 10titik, Profometer 10titik.Dengan batasan yang diperlukan untuk perbaikan struktur menggunakan mutu beton K250, Analisis data perhitungan antara beton tanpa GFRP dan memakai GFRP. 2 lapis. Hingga 5 lapis.
\end{abstract}

Kata kunci: perkuatan lentur balok dan plat beton bertulang,uji sampel beton silinder laboratorium, lapisGFRP

\section{PENDAHULUAN.}

Dengan perkembangan daerah putat jaya yang beralih fungsi sebagai daerah prostitusi menjadi daerah permukiman, pemerintah kota Surabaya mengembangkan perekonomian warga setempat dengan merenovasi gedung wisma Barbara menjadi lebih layak huni sebagai pemberdayaan masyarakat dengan meningkatkan sumber mata pencaharian. Terkait hal tersebut, maka gedung yang akan digunakan disesuaikan dengan kebutuhan, oleh sebab itu dilakukan tata letak ruang untuk memenuhi target usulan produksi yang akan dicapai sesuai program pemerintah kota.

Zona gedung terbagi menjadi produksi, $\mathrm{R}$ Perkantoran,R Kerja dan R. pertemuan, sehingga diperlukan kajian mendalam terhadap beban hidup terhadap struktur gedung existing, sehingga perlu dihitung ulang kelayakan struktur gedung dengan metode GFRP yang sedang berkembang saat ini. Sehubungan dengan hal tersebut ditunjuk konsultan perencana untuk mendesain ulang tata letak ruang yang lebih harmonis sebagai bagian yang tidak terpisahkan dengan keinginan pemerintah kota Surabaya.
Salah satu material yang akan digunakan GFRP ( Glass fiber reinforced polymer), karena kuat tarik fiber glass yang tinggi mampu menahan gaya tarik yang menambah peran baja tulangan sebagai tulangan tarik.Karena keruntuhan balok terjadi pada bending momen dan gaya geser lentur,aksial dan puntir.

GFRP dibuat dari pabrikan berbentuk woven serat yang akan direkatkan dengan polyester/matrix secara berlapis tergantung perhitungan struktur.cara pemasangan searah sumbu balok pada tumpuan dan lapangan.

Penelitian ini bertujuan untuk meningkatkan kekuatan struktur elemen balok lentur dan geser lentur yang mampu menerima beban vertikal sesuai kebutuhan peruntukan.Sehingga pemilik tidak ada keraguan dalam pemanfaatan gedung tersebut.

\section{KAJIAN PUSTAKA DAN TEORI}

Perkuatan Struktur dengan menggunakan bahan (Glass Fiber Reinforced Plastics - GFRP), terdiri dari komponen Reinforcement/filler/fiber serat gelas dan matrix juga tergantung substrat/bahan terlapisi. Salah satu bagian utama dari komposit adalah reinforcement (penguat) yang berfungsi sebagai penanggung beban utama pada komposit. 
Adanya dua penyusun komposit atau lebih menimbulkan beberapa daerah dan istilah penyebutannya; Matrik (penyusun dengan fraksi volume terbesar),Penguat (Penahan beban utama), Interphase (pelekat antar dua penyusun), interface (permukaan phase yang berbatasan dengan phase lain) Komposit adalah suatu jenis bahan baru hasil rekayasa yang terdiri dari dua atau lebih bahan dimana sifat masing-masing bahan berbeda satu sama lainnya baik itu sifat kimia maupun fisikanya dan tetap terpisah dalam hasil akhir bahan tersebut (bahan komposit). Dengan adanya perbedaan dari material penyusunnya maka komposit antar material harus berikatan dengan kuat,sehingga perlu adanya penambahan wetting agent(Nurun Nayiroh).

GFRP merupakan material komposit,yaitu komposit dari serat gelas di dalam matrik polymer. Serat berfungsi sebagai pemerkuat, sedangkan matrik berfungsi sebagai pemegang serat agar tidak bergeser, pelindung filamen terhadap goresan dan zat kimia ganas serta pelintas tegangan ke serat ( Feldman dan Hartomo,1995).

Studi untuk penggunaannya pada perkuatan balok telah dilakukan oleh beberapa peneliti seperti Norris et. al (1997) yang menggunakan pelat FRP untuk perkuatan geser yang direkatkan pada sisi samping balok. Ross et.al (1999) telah menunjukkan bahwa balok yang direkatkan dengan pelat FRP pada sisi tarik dapat meningkatkan kapasitas lentur balok secara nyata. Christos et. al. (2009) Penambahan lapis GFRP juga dapat meningkatkan kuat lentur balok, dimana pada penambahan 1 lapis GFRP terjadi peningkatan sebesar 10,8\% dengan model keruntuhan yang terjadi yaitu keruntuhan lentur yang disertai dengan putusnya GFRP.

Sedangkan pada penambahan 2 lapis GFRP terjadi peningkatan kuat lentur sebesar 13,4 \% dengan model keruntuhan yang terjadi yaitu keruntuhan lentur yang disertai dengan pelepasan lekatan antara GFRP dengan beton (debonding). I Ketut Sudarsana dan Ida Bagus Rai Widiarsa $(, 2008)$

Terkait dengan hal tersebut,adalah penting sebagai tehnologi tepat guna dalam penggunaan renovasi perkuatan beton bertulang dengan penambahan bahan GFRP sebagai metode perkuatan untuk mengembalikan atau meningkatkan kemampuan elemen struktur beton bertulang yang telah mengalami kegagalan akibat pelelehan tulangan

\section{, METODE PENELITIAN \& DATA}

Tahapan yang dilaksanakan dalam study adalah data-data yang dipakai :

1.Data Sekunder.

2.Data Primer

3.Uji Laboratorium

4.Uji Lendutan konvensional.
1. Tahap awal dari pekerjaan evaluasi dilakukakan untuk mempelajari data sekunder dari struktur gedung yang akan dimanfaatkan sebagai fungsi ruang kebutuhan pemberdayaan masyarakat. Selanjutnya dipastikan dengan mengadakan survey lapangan yang terkait dengan dimensi struktur dan penetapan system pengetesan lapangan

2. Sampel benda uji yang diambil adalah struktur plat dan balok, pengambilan secara acak dan yang paling lemah

3. Baja tulangan diambil dari sisa baja yang menempel pada plat, test kekuatan dan keseragaman beton yang dikerjakan dilapangan dilakukan dengan bor inti beton dan hammer test.

4. Guna mengetahui mutu baja tulangan yang terpasang dilakukan test uji kuat tarik baja yang dilakukan di laboratorium, Kedua mutu bahan yang diuji Ini dapat dipakai sebagai dasar guna menetapkan kemampuan dari elemen-elemen struktur yang terpasang

5. Sebelum dilakukan penempelan lahan, existing dibersihkan terlebih dahulu dari bongkaran keramik dan pasta semen dikupas hingga permukaan beton terlihat, perataan pada permukaan beton dengan grinda. Pembersihan dengan alat compressor hingga bersih dari kerakkerak pasta semen.dengan urutan sebagai berikut :

a. Semua sudut-sudut pada balok, kolom atau pilecap harus dibuat rounded atau lengkung

b. Setelah Perataan dan pembersihan dari debu maka dilakukan pekerjaan Primering dengan Resin Polyester dengan merata dan tertutup semua permukaan. (Jika terdapat retakan atau gupilan maka harus digroutting atau pelindungan dengan korosif pada besinya.)

c. Pelaburan Resin Polyester sebagai Perekatan FRP EWR 600 pertama dilakukan dengan waktu $\pm 2-3$ jam atau sebelum Setting maka FRP EWR600 ditempelkan merata sesuai gambar dan perhitungan struktur ...ulangangi tahap ini hingga selesai jumlah lapis sesuai gambar dan analisa struktur ( jeda waktu tiap lapis 5-7 jam)

d. Pekerjaan Finishing yaitu menutup dan meratakan permukaan dengan Resin Polyester atau Resi Epoxy hingga rata atau penaburan pasir jika dibutuhkan pekerjaan plesteran atau diberi kawat ayam

e. Selesai. 


\section{Data Umum Gedung}

- Fungsi Gedung Masyarakat.

- $\quad$ Lokasi Gedung Timur

- Tinggi Gedung

: It 6.

- Umur rencana bangunan: 50 tahun

\section{Peraturan dan Standar}

Peraturan dan standar yang dijadikan acuan/referensi dalam pekerjaan study ini dapat diuraikan sebagai berikut.

Pembebanan dan perhitungan

- SNI 1727-1989-F: "Tata Cara Perencanaan Pembebanan Untuk Rumah dan Gedung";

- SNI 1727-2012: "Tata Cara Perencanaan Pembebanan Untuk Rumah dan Gedung";

- SNI 1726-2002: "Peraturan Perencanaan Tahan Gempa Indonesia";

- SNI 1726-2012: "Peraturan Perencanaan Tahan Gempa Indonesia";

- SNI 2847-2013: "Tata Cara Perhitungan Struktur Beton Untuk Bangunan Gedung";

\section{Data Laboratorium:}

Data hasil uji laboratoriumt:

\section{Tabel 1:}


\begin{tabular}{|l|c|c|c|c|c|c|}
\hline \begin{tabular}{l}
\hline \\
10t
\end{tabular} & tex & $\begin{array}{c}\text { Density } \\
\text { (roving/10cm } \\
1\end{array}$ & $\begin{array}{c}\text { Moisture } \\
(\%)\end{array}$ & $\begin{array}{c}\text { Loss } \\
\text { on } \\
\text { ignitio } \\
n[\%)\end{array}$ & $\begin{array}{c}\text { Tensile } \\
\text { strength on } \\
\text { warp(N) }\end{array}$ & $\begin{array}{c}\text { Tensile } \\
\text { strength } \\
\text { on } \\
\text { weft/N) }\end{array}$ \\
\hline$\%$ & $\begin{array}{c}1200 \pm 5 \\
\%\end{array}$ & $25 \pm 10 \%$ & 50.2 & $\begin{array}{c}0.4 \sim \\
0.8\end{array}$ & 24000 & 23850 \\
\hline
\end{tabular}

Brosur : vendor FRP

Jenis carbon dari jepang dan china pada gambar 1 dan2

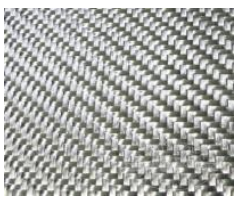

Gambar 1: Kyoto Carbon Fiber WR167

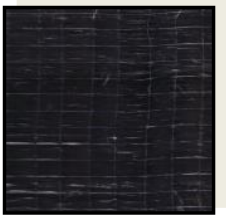

Gambar 2: Shandong Fiberglass WR600

\section{HASIL \& PEMBAHASAN.}

Langkah-langkah yang dilakukan di site diperlihatkan pada gambar 1, 2 dan 3.

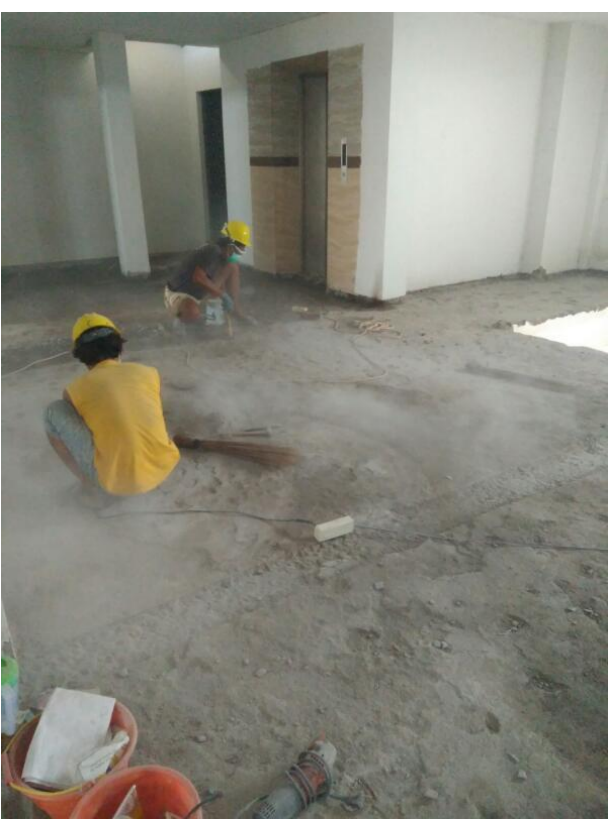

Gambar 1: pengupasan lantai keramik.dan perataan lantai beton 




Gambar 2: pelapisan FRP dengan polyester.

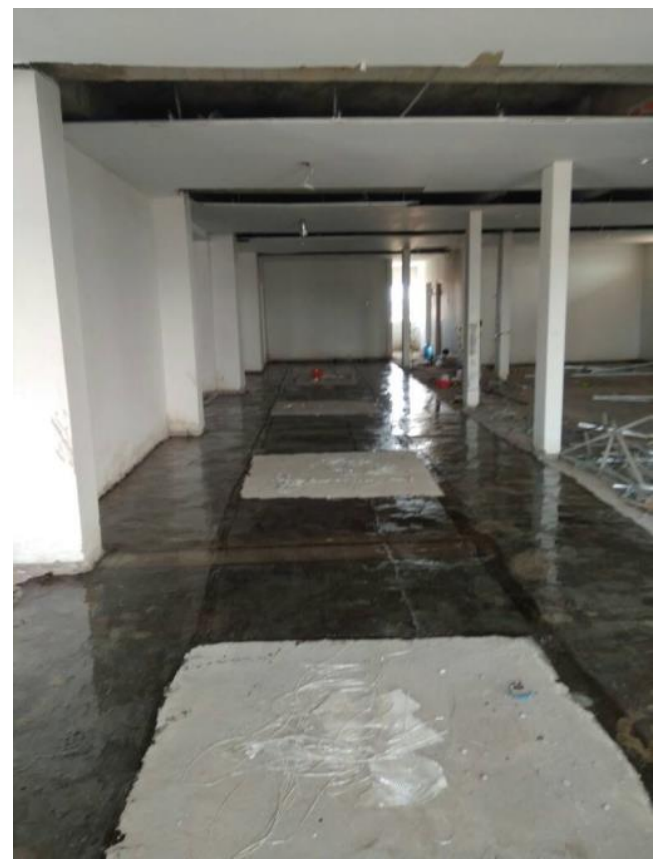

Gambar3: pelapisan daerah plat tumpuan sudah selesai.

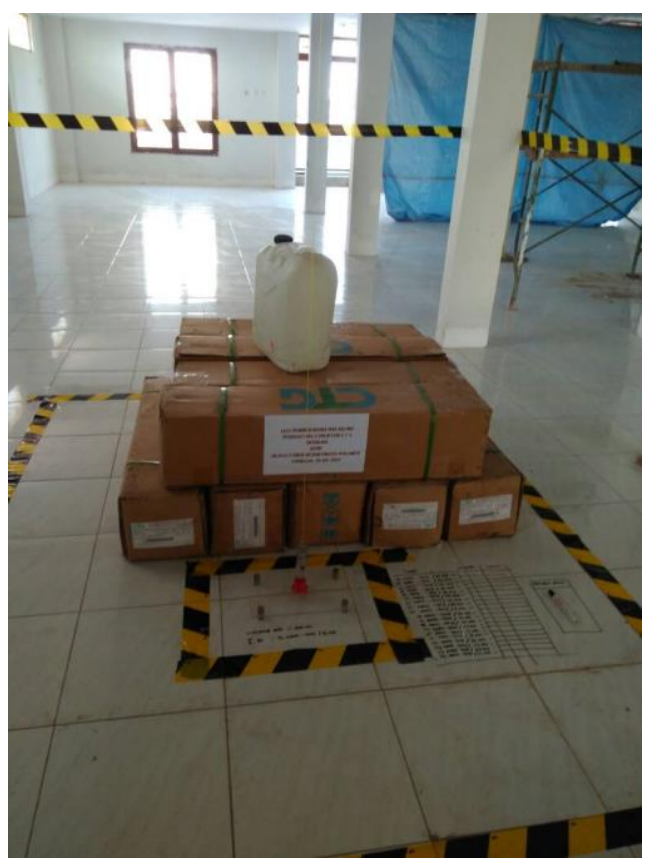

Gambar4: uji beban manual dengan bahan paking FRP seberat $400 \mathrm{~kg}$.

Langkah-langkah perhitungan struktur balok dan plat dengan memakai GFRP diperlihatkan pada tabel 1 perhitungan plat,tabel 2 perhitungan balok.

Tabel1: perhitungan plat.

\section{PERHITUNGAN PLAT LANTAI (SLAB) GEDUNG BARBARA DOLLY SURABAYA} PLAT LENTUR DUA ARAH (TWO WAY SLAB) PERKUATAN FRP EWR 600

\section{A. DATA BAHAN STRUKTUR}

\begin{tabular}{|c|c|c|c|}
\hline Kuat tekan beton, & $f_{c}^{\prime}=$ & 21 & $\mathrm{MPa}$ \\
\hline Tegangan leleh baja untuk tulangan lentur. & $f_{y}=$ & 240 & $\mathrm{MPa}$ \\
\hline Tebal bersih selimut beton. & $t_{b}=$ & 25 & $\mathrm{~mm}$ \\
\hline Faktor Reduksi Lingkungan & $C_{e}=$ & 0.85 & \\
\hline Kuat tark Utiomate FRP & $f_{i^{\prime \prime}}=$ & $2,345.00$ & $\mathrm{MPa}$ \\
\hline Regangan Pecah FRP & $\varepsilon_{\mathrm{fu}}^{*}=$ & 0.0213 & $\mathrm{~mm} / \mathrm{mr}$ \\
\hline Modulus elasitas FRP & $E f=$ & $70,000.00$ & \\
\hline Tebal FRP WR 600 & $\mathrm{Tf}=$ & 0.6 & mm \\
\hline Modulus elasitas Baja & $E_{s}=$ & $200,000.00$ & $\mathrm{MPa}$ \\
\hline Modulus elasitas Beton & $E_{c}=$ & 21.409 .52 & $\mathrm{MPa}$ \\
\hline
\end{tabular}

\section{B. DATA PLAT LANTAI}

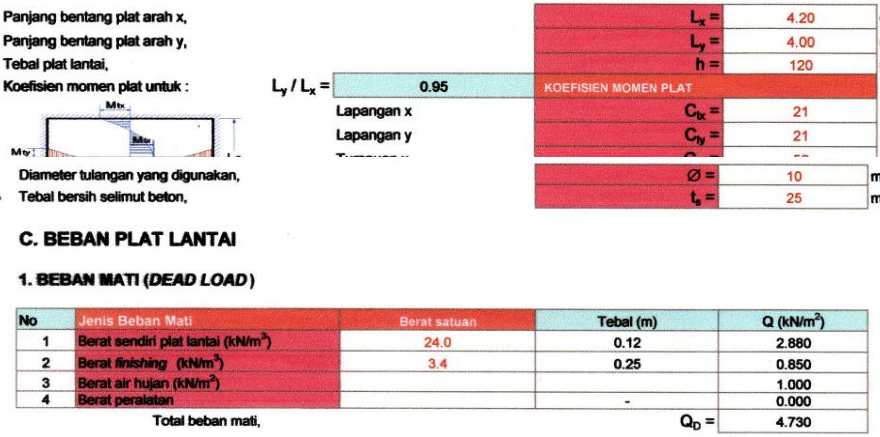

2. BEBAN HIDUP (LNE LOAD)

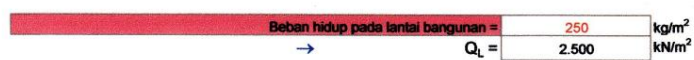




\section{BEBAN RENCANA TERFAKTOR}

Beban rencana terfakitor

\section{MOMEN PLAT AKIBAT BEBAN TERFAKTOR}

\section{Momen lapangan arah $x$}

Momen lapangan arah $y$,

Momen tumpuan arah $x$,

Momen tumpuan arah $y$,

Momen rencana (maksimum) plat,

$$
Q_{U}=1.2 * Q_{0}+1.6 * Q_{L}=9.676 \mathrm{kNm}^{2}
$$

\begin{tabular}{|c|c|}
\hline$M_{L x}=C_{x x} * 0.001 * Q_{u}^{*}{ }^{*} L_{x}^{2}=$ & 3.584 \\
\hline$M_{v y}=C_{y y}{ }^{*} 0.001 * Q_{u}{ }^{*} L_{x}^{2}=$ & 3.584 \\
\hline$M_{t a}=C_{x} \cdot 0.001 * Q_{u} * L_{x}^{2}=$ & 8.876 \\
\hline$M_{v t}=C_{y}{ }^{*} 0.001{ }^{*} Q_{u}{ }^{*} L_{x}^{2}=$ & 8.876 \\
\hline$M_{v}=$ & 8.876 \\
\hline
\end{tabular}

Rasio tulangan yeng dipertukan:

Rasio tuangan minimum,

Rasio tulangan yang digunakan,

Luas tulangan yang dipertukan,

Jarak tulangan yang diperikan,

Jarak tulangan maksimum,

Jarak tulangan maksimum,

Jarak sengkang yang harus digunakan

Diambil jarak sengkang :

Digunakan tulangen,

Luas tulangan terpakai,

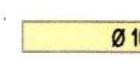

$\rho=0.85^{*} f_{c}^{\prime} / f_{y}^{*}\left[1-\sqrt{ }\left[1-2 * R_{n} /\left(0.85{ }^{*} f_{c}^{\prime}\right)\right]=0.0059\right.$

$\begin{array}{rlr}\rho_{\min } & =0.0025 \\ \rho & =0.0059 \\ A_{9}=\rho * b^{*} d= & 535\end{array}$

$s=\pi / 4^{*} \theta^{2} * b / A_{1}=147$ $S_{\max }=2 * h=240$

$S_{\max }=200 \quad \mathrm{~mm}$

$s=147 \mathrm{~mm}$

$s=140 \quad \mathrm{~mm}$

Tulangan Terpasang

Luas tulangan terpasang

\begin{tabular}{|c|c|c|}
\hline$\emptyset 10$ & . & 150 \\
\hline & $A_{3}=\pi / 4^{*} \oslash^{2 *} b / s=$ & 524 \\
\hline
\end{tabular}

Berdasarkan kondisi diatas maka luas penampang besi yang dibutukhan kurang yaitu:

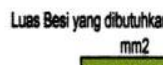

\begin{tabular}{|l|l}
$\mathrm{mm} 2$ \\
\hline 535 \\
\hline
\end{tabular}

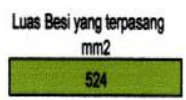

B. PERHITUNGAN LENTUR PLAT SETELAH PERKUATAN FRP 1 LAPIS ARAH X DANY

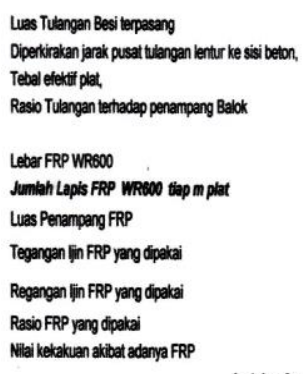

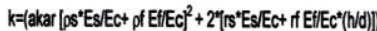

Kontrol Assumsi Nilaic

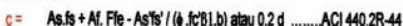

Momen Inetia Penampang FRP + Plat beton

Regangen Eletetif $F R P<k$ c cuu $=0,12 \times 0,0202=0,002424=$
Tingkat regangan beton pecta katan FRP

Tegangan Eftedtr FRP

Untuk : $: f_{c}^{\prime}>30 \mathrm{MPa}$

Faktor bentik distribusi legangan beton,

Faktor reduksi kekuatan lentur.

Naia pertitungan diatas dapat digunakan se

naan sebagai Beriku

Momen negastif nominal renceana.

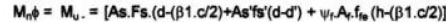

$\varepsilon_{\mathrm{ml}}=(\mathrm{MDL} \cdot(h-k)) M \mathrm{Cr}^{\circ} \mathrm{EC}=\quad 0.00190$ $f_{t o}=E F \cdot \varepsilon_{t 0}=168.00$

$\begin{aligned} \beta_{1} & =0.85 \\ \beta_{1}=0.85-0.05^{\circ}\left(f^{\prime}-30\right) / 7 & =0.00 \\ & \end{aligned}$

$\rightarrow \quad \beta_{1}=\quad 0.85$

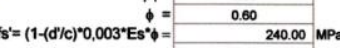

lok setelah diperkuat

$=20,776,072.97 \mathrm{Nmm}$ $\begin{array}{ll} & =20.78 \mathrm{KNm} \\ & =\quad 2.08 \mathrm{TON-m}\end{array}$

Syarat: $\begin{array}{llll}\cdot \cdot M_{n} & 2 & M_{u}- & \\ 20.78 & > & 2.88 & \text { AMAN (OK) }\end{array}$

Luas tulangan terpeseano.

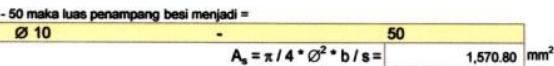

Untuk : $\mathrm{fc}_{\mathrm{c}}^{\prime} \leq 30 \mathrm{MPa}$

Untuk : $f_{c}^{\prime}>30 \mathrm{MPa}$,

Faktor bentuk distritusi tegangan beton

Rasio tulangan pada kondisi balance,

Faktor tahanan momen maksimum

Faktor reduksi kekuatan lentur,

Jarak tulangan terhadap sisi ivar beton

Tebal etectif plat lantai,

Ditinju plat lantai selebar $1 \mathrm{~m}$,

Momen nominal rencana,

Fattor tahanan momen,

$R_{n}<R_{\max }$

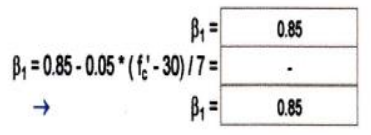

$p_{b}=\beta_{1}{ }^{*} 0.85{ }^{*} f_{c}^{\prime} / f_{y}{ }^{*} 600 /\left(600+f_{y}\right)=0.0446$

$R_{\max }=0.75^{*} p_{0}{ }^{*} f_{y}{ }^{*}\left[1-1^{*} 2^{*} 0.75^{*} p_{0}^{*} f_{y} /\left(0.85^{*} f_{c}^{\prime}\right)\right]=6.2028$

\begin{tabular}{|c|c|}
\hline $\left.5^{\circ} \rho_{0}{ }^{\circ} t_{y} /\left(0.85^{*} f_{c}\right)\right]$ & 6.2028 \\
\hline$\phi=$ & 0.80 \\
\hline$d_{s}=t_{s}+\varnothing / 2=$ & 30.0 \\
\hline$d=h-d_{s}=$ & 80.0 \\
\hline$b=$ & 1000 \\
\hline$M_{n}=M_{w} / \phi=$ & 11.095 \\
\hline$R_{n}=M_{n} * 10^{8} /\left(b^{*} d^{2}\right)=$ & 1.36969 \\
\hline
\end{tabular}

B. PENULANGAN PLAT ARAH X TUMPUAN

$\rightarrow \quad(\mathrm{KK})$

Jerak sengkeng yeng havss digunatian.

$A_{4}=\rho * b * d=525$ (rs'Es/EC+ + EffEC)

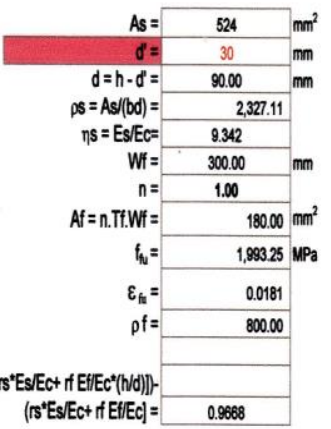

Untuk : $f_{c^{\prime}} \leq 30 \mathrm{MPa}$,

Untuk: $f_{c}^{\prime}>30 \mathrm{MPa}$

Faktor bentuk distribusi tegangan beton,

Rasio tulangan pada kondisi belance,

Faktor tahanan momen maksimum

Faktor reduksi kekuatan lentur

Jarak tulangan terhadap sisi luar beton,

Tebal efektif plat lantai,

Ditinjau plat lantai selebar $1 \mathrm{~m}$,

Momen nominal rencana.

Faktor tahanan momen,

Rasio tulangan yang dipertukan: $\mathbf{R}_{\mathbf{n}}<-\mathbf{R}_{\max }$

Rasio tutangan minimum

Rasio tulangan yang dign

Luas tulangan yeng dipertukan,

Jarak tulangan yang dipertukan

Jarak tulangan maksimum,

Jarak tulangan maksimum,

Diambil jarak sengkang :

Digunakan tulangan.

Luas tulangan terpakin:

Tulangan Terpasene.

unas ulangan terpesseng.



$\beta_{1}=0.85-0.05 *\left(f_{c}^{\prime}-30\right) / 7=$

$p_{b}=\beta_{1}{ }^{*} 0.85 * f_{c}^{\prime} / f_{y} * 600 /\left(600+f_{y}\right)$

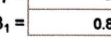

$R_{\text {max }}=0.75 * \rho_{b}^{*} f_{y}{ }^{*}\left[1-1 / 2^{*} 0.75 * \rho_{b}^{*} f_{y} /\left(0.85 * f_{c}^{\prime}\right)\right]$

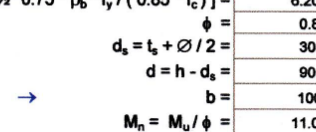

6.2028

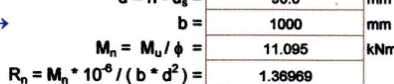

$\rho=0.85^{*} f_{c}^{\prime} / f_{y} \cdot{ }^{*}\left[1-\sqrt{ }\left[1-2 \cdot R_{n} /\left(0.85{ }^{*} f_{c}^{\prime}\right)\right]=0.0059\right.$

$\rho_{\min }=\sqrt{f_{c}^{\prime} /\left(4^{*} f_{y}\right)}=\quad 0.0007$

$\begin{aligned} \rho_{m m}=1.4 / f_{y} & =0.0058 \\ \rho & =0.059\end{aligned}$

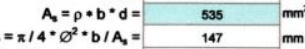

$S_{\text {max }}=2^{*} h=\quad 240 \quad \mathrm{~mm}$



$s={ }_{140} \quad 140 \quad \mathrm{~mm}$

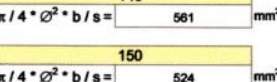

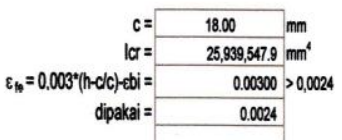


Tabel2: perhitungan balok.

PERHITUNGAN BALOK (BEAM) DGN PERKUATAN FRP EWR 600 BALOK $200 / 320 \mathrm{GDG}$ BARBARA DOLLY SURABAYA L $=6 \mathrm{M}$

\section{Struktur Engineer: :H. Eóy Jayanto (Hp. 082330592315)}

Lokasi Tulangan Tumpuan

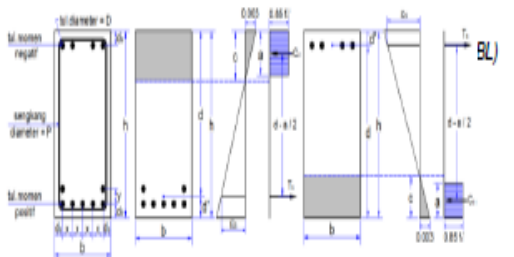

\section{A. DATABALOK LANTAI}

\begin{tabular}{|c|c|c|}
\hline \multicolumn{3}{|l|}{ BAHAN STRUKTUR } \\
\hline Kuat tekan beton, & $f_{c}^{\prime}=$ & 20.8 \\
\hline Tegangan leleh baja (defom) untuk tulangan lentur, & $f_{y}=$ & 400 \\
\hline Tegangan leleh baja (polos) untuk tulangan geser, & $t_{y}=$ & 240 \\
\hline \multicolumn{3}{|l|}{ DIMENSI BALOK } \\
\hline Lebar balok & $b=$ & 150 \\
\hline Tinggi balok & $h=$ & 320 \\
\hline Diameter tulangan (deform) yang digunakan, & $D=$ & 18 \\
\hline Diameter sengkang (polos) yang digunakan, & $P=$ & 10 \\
\hline Tebal bersih selimut beton, & $t_{b}=$ & 25 \\
\hline Faktor Reduksi Lingkungan & $\mathrm{Ce}=$ & 0.85 \\
\hline Kuat tark Ultimate FRP & $f_{n}^{\prime}=$ & $2,200.00$ \\
\hline Regangan Pecah FRP & $\varepsilon_{n}^{n}=$ & 0.0213 \\
\hline Modulus elasitas FRP & $E f=$ & $70,000.00$ \\
\hline Tebal FRP & $T f=$ & 0.6 \\
\hline Modulus elasitas Baia & $E_{5}=$ & $200,000.00$ \\
\hline Modulus elasitas Beton & $E_{c}=$ & $21,400.52$ \\
\hline \multicolumn{3}{|l|}{ MOMEN DAN GAYA GESER RENCANA } \\
\hline Momen rencana positf akibat beban terfaktor, & $M_{0}^{*}=$ & 78.31 \\
\hline Momen rencana negatf akbat beban terfiaktor, & $M_{u}{ }^{\circ}=$ & 158.61 \\
\hline Gaya geser rencana akbat beban terfaktor, & $V_{u}=$ & 113.51 \\
\hline
\end{tabular}

\section{B. PERHITUNGAN LENTUR BALOK SETELAH PERKUATAN FRP}

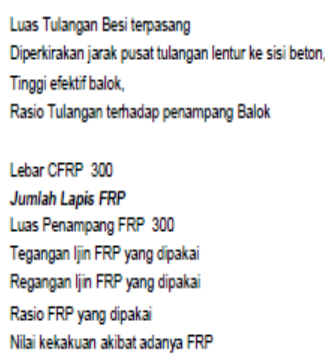

Kontrol Assumsi Nilai c

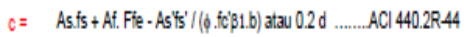

Momen Inerta Penampang FRP + Balok beton

Regangan Effektff CFRP $<\mathrm{km}$ efu $=0,12 \times 0,0202=0,002424=$

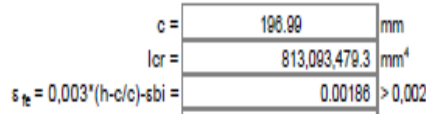

khusus material Glass ewro0 Regangan =

Tingkat regangan beton pada ikatan FRP $\varepsilon_{u=}=\left(M^{\prime} L^{\prime}(h-k)\right) / c r^{\prime} E_{C}$

0.0024

Tegangan Effektif FRP

Untuk : $f_{c}^{\prime} \leq 30 \mathrm{MPa}$

Untuk : $f_{c}^{\prime}>30 \mathrm{MPa}$

Faktor bentuk distribusi tegangan beton,

Faktor reduksi kekuatan lentur,

$f_{\mathrm{te}}=\mathrm{EF}^{\mathrm{x}} \mathrm{8}_{\mathrm{e}}=$

$$
\beta_{1}=
$$

$\beta_{1}=0.85-0.05^{\prime}\left(f_{c}^{\prime}-30\right) / 7$

$\rightarrow \quad \beta_{1}=0.08$

$\phi=$

$f s^{\prime}=\left(1-\left(d^{\prime} / c\right)^{\prime} 0,003^{\prime} E s\right.$

\begin{tabular}{|c|}
\hline 0.80 \\
\hline $\mathrm{MPa}$
\end{tabular}

Nila perhitungan diatas dapat digunakan sebagai dasar pertitungan kapasitas Balok setelah diperkuat dengan FRP dengan Persamaan sebagai Berikut:

Momen negafif nominal rencana,

$M_{n} \hat{\theta}=M_{u}=\left[A s . F s .\left(d-(\beta 1 . d / 2)+A s^{\prime} f^{\prime}\left(d-d^{\prime}\right)+\psi_{+} \cdot A_{+} f_{t e}(h-(B 1 . c / 2)]\right.\right.$

- $\quad 181,562,789.27 \mathrm{Nmm}$ - $\quad 181.56 \mathrm{kNm}$

Syarat:

$\frac{6^{2} \mathrm{M}_{\mathrm{n}}}{181.56}$

$M_{4}$ 18.16 TON-M

\section{PERHITUNGAN GESER BALOK SETELAH PERKUATAN FRP}

Luas Penampang FRP sengkang Tegangan FRP untuk sengkang Regangan effektf FRP untuk sengkang

Lebar FRP untuk sengkang

Panjang FRP untuk sengkang

Panjang FRP untuk seng

Kapasitas geser yang diberkan deh FRP

Faktor reduksi untuk geser

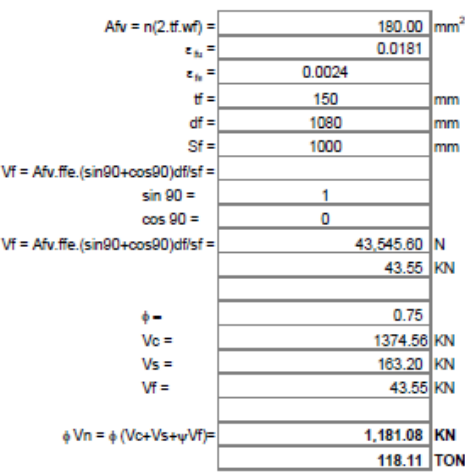

Kapasitas geser balok setelah dilakukan perkuatan FRP

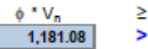




\section{KESIMPULAN \& SARAN.}

Dari hasil studi dan pembahasan kemampuan beton bertulang dengan metode penambahan dengan GFRP pada bending momen sebagai berikut :

1. Berdasarkan Perhitungan balok bertulang existing 200/320 dengan penambahan GFRP $\phi \mathrm{Mn}>\mathrm{Mu}$ $\phi \mathrm{Mn}=181,56 \mathrm{KNm}, \mathrm{Mu}=156,61 \mathrm{KNm} \ldots \ldots . . . \mathrm{ok}$ $\phi \mathrm{Vn}=1.181,08 \mathrm{KN}, \mathrm{Vu}=113,51 \mathrm{KN} \ldots \ldots . . \mathrm{ok}$

2. Berdasarkan Perhitungan Plat bertulang existing tebal $12 \mathrm{~cm}$ dengan penambahan GFRP $\phi \mathrm{Mn}>\mathrm{Mu}$ $\phi \mathrm{Mn}=20,78 \mathrm{KNm}, \mathrm{Mu}=8,88 \mathrm{KNm} \ldots \ldots . . \mathrm{ok}$ $\delta=8.473 \mathrm{~mm}, \delta$ ijin $=\mathrm{L} / 480=8.750 \mathrm{~mm}$........ok

3. Dilapangan dipakai 5 lapis serat $90^{\circ}, 0^{\circ}$ sebagai faktor keamanan.

\section{DAFTAR PUSTAKA}

- Parno Taufikurrahman. (2014). "Perbaikan Kekuatan dan Daktilitas Balok Beton Bertulang Menggunakan Glass Fiber Reinforced Polimer (GFRP) Strips.”. Journal Ilmu-Ilmu TeknikSistem.

- Rudy Jamauddin dan shinichi Hino. (2011). "Kapasitas Perkuatan Lentur Balok beton bertulang yang telah meleleh dengan menggunakan lembaran GFRP'. Journal dinamika teknik sipil.

- Mozartha et.al. (2009). "Pemilihan Resin Komposit dan Fiber untuk meningkatkan kekuatan flektural". Journal PDGI 59..

- Tavio, Purwono, $\mathrm{R}$ dan Sosyidah, A. "Peningkatan Daya Dukung dan Daktilitas Balok Beton Bertulang Dengan Menggunakan Perkuatan CFRP (Carbon Fiber Reinforced Polymer" Dinamika Teknik Sipil, 2009

- Feldman, D. dan Hartomo, A.J. (1995), Bahan Polimer Konstruksi Bangunan, PT. Gramedia Pustaka Utama,Jakarta, 117 pp.

- Nawy, E.G. 1990. Beton Bertulang Suatu Pendekatan Dasar, PT. Eresco, Bandung, 763 pp. 